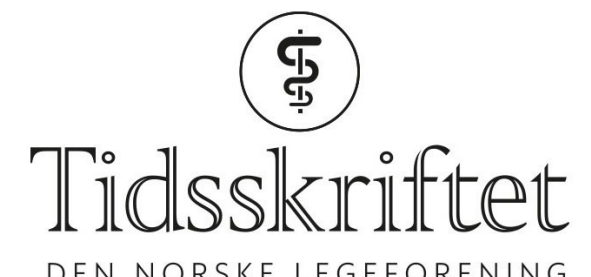

DEN NORSKE LEGEFORENING

\title{
Screening for tarmkreft har effekt, men bare for menn
}

FRA ANDRE TIDSSKRIFTER

ØYVIND STOPLE SIVERTSEN

Tidsskriftet

Sigmoidoskopi har vist gode resultater hos menn 15 år etter screening. Dette viser en norsk studie som er publisert i Annals of Internal Medicine.

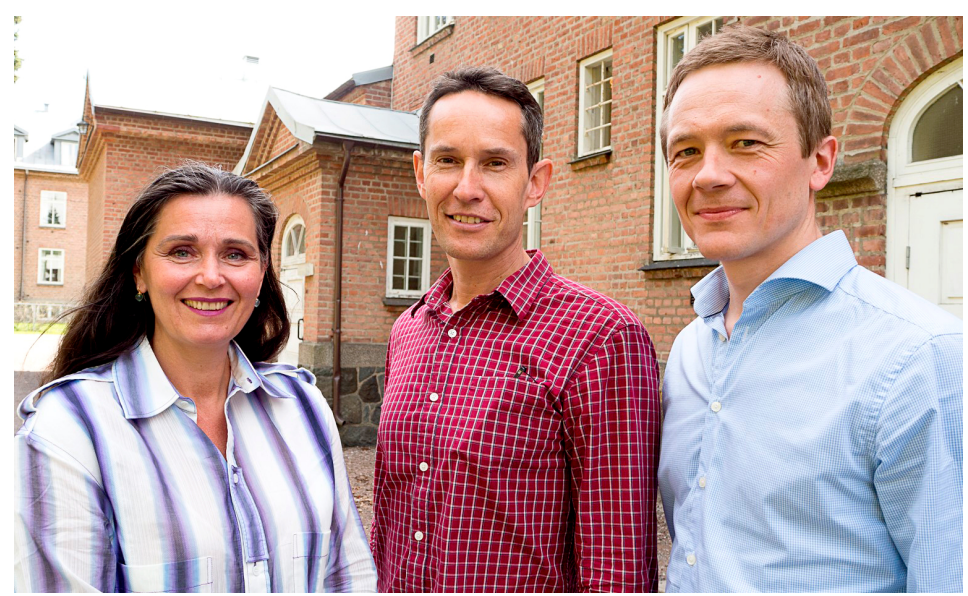

De tre førsteforfatterne av artikkelen Mette Kalager (t.v.), Øyvind Holme, Magnus Løberg. Foto: Anita Aalby

I studien ble nærmere 100 ooo norske kvinner og menn i alderen 50-64 år randomisert til screening med sigmoidoskopi eller ingen screening (1). Etter 15 års oppfølging var absolutt risiko for kolorektalkreft hos menn 1,72 \% i screeninggruppen og 2,50 \% i kontrollgruppen, dvs. en hasardratio på o,66 ( $95 \% \mathrm{KI}$ o,57-0,78). For kvinner var absolutt risiko henholdsvis 1,86\% og 2,05\% (hasardratio o,92; 0,79-1,07). Hasardratio for død av kolorektalkreft var 0,63 $\left(0,47^{-0}, 83\right)$ og 1,01 (o,77-1,33) for henholdsvis menn og kvinner.

- Resultatene fra oppfølgingen etter 15 år er viktig av flere grunner, sier Øyvind Holme, leder av tarmscreeningseksjonen ved Kreftregisteret og en av artikkelens tre førsteforfattere.

- For det første viser de at sigmoidoskopi er et godt screeningverktøy for menn; en fem minutters screeningunders $\emptyset$ kelse reduserer forekomst og død av tarmkreft med ca. $35 \%$. Det betyr at 15-årsrisiko for tykktarmskreft blir redusert fra 2,5\% til 1,7 \%, mens risiko for død av tykktarmskreft faller fra o,8 \% til o,5\%. For det andre viser resultatene at screening for tarmkreft ikke nødvendigvis er like effektiv for begge kjønn. For kvinner fant vi ingen reduksjon i forekomst eller $\mathrm{d} ø \mathrm{~d}$ av tarmkreft etter screening med sigmoidoskopi. Det er uvisst om andre metoder for tykktarmscreening, slik som koloskopi og immunologisk test 
for blod i avføringen, har ulik effekt for kvinner og menn. - Våre funn viser med all tydelighet at et screeningtilbud ikke må innføres i befolkningen før det er tilstrekkelig vurdert i randomiserte studier, sier Holme.

De tre førsteforfatterne arbeider ved Oslo universitetssykehus og Senter for klinisk effektforskning ved Universitetet i Oslo. Denne gruppen ble startet i 2012 av Michael Bretthauer og Mette Kalager. Gruppens viktigste arbeidsområde er å vurdere effekt av diagnostiske og terapeutiske intervensjoner på ulike kliniske problemstillinger. De gjennomfører randomiserte studier med over 300 ooo inkluderte personer og observasjonelle studier med bruk av pasientinformasjon fra journaler og koblinger til registre. Gruppen anvender og utvikler nye statistiske metoder i samarbeid med forskere i utlandet, spesielt USA, forteller Holme.

Gruppens uttalte mål er å bryte barrierer og sette spørsmåltegn ved etablerte sannheter.

- Vi ønsker å gjøre de studiene andre ikke gjør, ikke fordi de ikke er viktige, men fordi de er vanskelige, sier Holme. Gruppen arbeider aktivt med å bygge opp en kritisk masse av studier og er opptatt av teamarbeid og internasjonal samarbeid. I 2017 hadde gruppen hadde hele fem originalartikler i tidsskriftene New England Journal of Medicine, The Lancet, The BMJ og Annals of Internal Medicine, ofte omtalt å være blant «de fem store».

\section{LITTERATUR:}

1. Holme $\emptyset$, Løberg M, Kalager M et al. Long-term effectiveness of sigmoidoscopy screening on colorectal cancer incidence and mortality in women and men: a randomized trial. Ann Intern Med 2018; $168: 775-82$.

Publisert: 1. oktober 2018. Tidsskr Nor Legeforen. DOI: 10.4045/tidsskr.18.o6o8

(C) Tidsskrift for Den norske legeforening 2020. Lastet ned fra tidsskriftet.no 